Tionne Raats

Postgraduate, Department of French

\title{
ARTHUR RIMBAUD: FRENCH SYMBOLIST
}

\section{Rimbaud and reality}

Rimbaud as a poet occupies a unique position in the history of French literature and with his theory of poetry he greatly influenced not only the Symbolist movement of which he was one of the chief initiators, but all of contemporary poetry.

What makes his influence all the more astounding is the fact that his poetic career lasted for approximately four short years. He started writing poetry at the age of sxteen and at twenty had renounced poetry for ever.

Arthur Rimbaud was born on 20 October 1854 in the small industrial town of Charleville, near the Belgian frontier. His father, a professional soldier, had an adventurous nature and soon found life in a small town intolerable. When Rimbaud was six years old his tather deserted his family and the children were left to be brought up by their mother. She was very strict and the severity of the poet's upbringing, in which piety and economy were the guiding principles, perhaps explains his rebellion against the world of narrow respectability during his adolescence.

Although he was a brilliant scholar at school and won the "Concours général" of 1869 with some Latin verses he wrote, he was constantly at war with all forms of aut hority, and even ran away from home a couple of times. In 1870 , for example, he ran away to Paris but had to return home for want of money. On another occasion he wandered through France and Belgium on foot before returning to Charleville and school. The memory of these escapades served as inspiration for mant of his earlier poems such as $L e$ Buffet. . Ma Boheme and Le Dormeur du Ial. All these poems are expressions of his innocent joy of life and love of liberty.

Having read and admired the work of Paul Verlaine, Rimbaud, on leaving school, decided to send some of his verse to the older poet. He then received an invitation to visit V'erlaine in Paris. The two met for first time in September 1871. Verlaine was fascinated by Rimbaud's talent and personality. The upshot of the meeting was that Verlaine abandoned his wile and infant son and wandered off with Rimbaud to Belgium and London. 
Their life together was one of debauchery and drunkenness. All social conventions and laws were thrown overboard by them. Their association lasted some eighteen months and was cut short when V'erlaine fired a gun at Rimbaud in a Brussels hotel and wounded him in the wrist. Verlaine was sentenced to two years' imprisonment and Rimbaud returned to Charleville where he finished writing l'ne saison en enfer. Between September 1874 and June 1875 he composed his last poems, which were later collected and published under the title Illuminations. After 1875 he stopped writing poetry.

Lntil his death in 1879, Rimbaud continued his roving existence, ending up in Harar, Abyssinia, $v$ here he became a trader and to a certain extent an explorer. The explorer of the ideal thus became the adventurer and explorer of the real. A painful tumour in his knee forced him to return to France where his leg was later amputated. He died on 10 November 1891 at the Hospital of the Conception at Marseille.

In poetry as in politics, Rimbaud was a revolutionary. He wanted to be a iovant. a seer, a man who sees beyond reality into the true nature of things and self. It was his belief that the task of the poet is the search for the unknow'n and the undiscovered. This was then also the reason why he abandoned himself to every form of physical and mental debauchery. He believed that by the deliberate disordering of the senses he could become "le suprême savani" - the supreme sage.

One can also see his excesses as the action of an adoloscent on the brink of life - who has no patience, then, to gain experience of life by degrees. He had to snatch at everything - experience, knowledge, understanding - even if it meant destroying himself in the process.

Rimbaud completed the Symbolist revolt against the traditional versification of the Parnassians, which Baudelaire had started. In his poetry he makes use of imparisyllabic lines (uneven numbers of syllables) and often mixes lines of different lengths. He often treats rbyme with the same indifference, inserting lines of blank verse in between ordinary rhyme patterns. Illuminations, for example, is a collection of prose poems.

Rimbaud often achieves his effect by piling up images which are both unexpected and striking. In th is way he succeeds in evoking in his reader the same sentiments that he experienced himself. His images are mainly visual. In contrast with Verlaine his perceptions are not primarily aural and his poctry therefore lacks the musicality which one finds in Verlaine's work. 


\section{Ma Bohème}

\section{Fantaisie}

As already mentioned, this poem was written early in Rimbaud's career, after one of his habitual flights from home. The poem is a regular sonnet consisting of an octave and a sestet and has a regular rhyme scheme.

The first quatrain of this sonnet presents the vagabond poet. The roving character of the poet is strongly underlined by the use of the indefinite verb. "Je m'en allais" evokes the impression of a repetitive action, of his habitually setting off to nowhere in particular. This indeed is escape from everything that restricts his freedom.

From the very first line we have the striking image of a tramp, characterized only by his shabby coat with its tattered pockets - so threadbare that it becomes almost intangible. This vagabond lives above the ordinary world and has no use for mundane things such as clothes. His attitude is insouciant and the tone of the whole poem is one of banter and playfulness. His poverty does not bother him, but is in fact a prerequisite for tranquility and freedom of spirit.

The word "idéal" in the third line launches the element of fantasy which he mentions in his sub-title. "J'allais sous le ciel", seems to dismiss all other aspects of nature from the mind's eye. The poet finds himself alone under the wide expanse of the sky. This image underlines the wonderful feeling of freedom that he is experiencing and his joy at being able to do what he really wants: to be the faithful follower of the Muse.

The archaic word "féal" evokes the medieval troubadours, themselves wanderers, singing their songs from court to court, and draws together the image of the tramp and the romanticized figure of a knight-errant serving his mistress.

But the Rimbaud who jeers at all grandiloquence and refuses to take himself seriously, exclaims:

"Oh! là là! que d'amours splendides j’ai rêvées!"

The change of tense in this line suggests a slightly older poet looking back on the aspirations of his younger self. In stark contrast to these splendid fancies. the poet recalls reality:

"Mon unique culotte avait un large trou" (1.5). 
In the poet's mind, wandering slightly perhaps as the result of hunger, he becomes the lost Tom Thumb who instead of pebbles or crumbs leaves a trail of verse behind him. The word "égrenais" also suggests the facility with which he composes his rhymes.

The enjambment in lines 6 and 7 , withholds the direct object "Des rimes" which gives a surprising twist to the metaphor and also underlines the fact that this adolescent tramping along the roads possesses something worth far more than all the treasures of the world: his poetry.

Thanks to his wonderful gift he can overcome hunger and fatigue and transport himself to an ide al world. He no longer walks the earth but finds himself in the sky resting in an inn which is peculiarly his own: "Mon auberge ...", "mes étoiles...". Once again he is emphasizing his wealth in spite of his apparent poverty.

Rimbaud's linguistic inventiveness is clearly illustrated in the synaesthesia of the eighth line:

"... Mes étoiles au ciel avaient un doux frou-frou".

Here the shining quality of the stars becomes a sound - the rustle of silk which in turn is suggested by the onomatopoeic word "frou-frou".

The picture of the vagabond poet is continued in the lirst tercet of the sestet. The rhythm changes, however, and becomes slower. The poet is no longer strolling along jauntily but is seated by the wayside, contemplating the beautiful evening.

Once again Rimbaud uses two hackneyed poetic images, that of dew as the gentle sustenance from heaven, and that of the poet's brow, and gives them a picturesque twist to create an entirely new and fresh image. In keeping with the idea of an inn where he is resting, the dew on his forehead becomes a wine which invigorates his whole body. In this way poetic inspiration becomes a physical sensation, and the abstract assumes concrete shape.

But this vision of the poet sitting by the roadside is too conventional for Rimbaud. He substitutes for it a caricature which is both provocative of laughter and sad. In the absence of a real lyre, the poct uses the elastic of his shoe to make music with which to accompany his thymes. In using the objective "blessés!" to describe his shoes, he is once ayain juxtaposing the sublime and the ridiculous. Instead of his hand over his heart, as is customary with troubadours. the poet sings his song with his foot against his heart! 
The picture of the poet in this highly improbable and uncomfortable position is also a view of poetry which is clearly self-mocking. We can perhaps find an implicit criticism of romanticism in this picture he creates. He irony sweeps away emotion and the ideal is replaced by the real.

In this poem where fantasy and realism are closely intermingled we find a good example of Rimbaud's poetic style. The rude contact with a reality which has been shorn of all adornment in Rimbaud's case does not stunt inspiration but rather encourages his flight into the ideal world.

\section{BIBLIOGRAPHY}

ARISSE.AL; P 1965. Littérature francaise expliquée. Paris. Les éditions de l'école.

BRERETON, G. 1957. An introduction to the Free poets. Villon to the present day. London, Methuen and Co. Lid.

BROOME, P. \& CHESTERS. G. 1976. The appreciation of Modern French Poetry (18501950. Cambridge L'niversity Press.

L.AG.ARIDE. A et Michard, L. 1969. XIXe Siècle - Les grands auteurs francais du programme. Paris, Bordas. 